\title{
Effect of Different Ultrasonic Amplitude Treatments on Corn Starch Gels
}

\author{
Gamze Üçok ${ }^{1 *}$ \\ $\mathbf{1}^{*}$ Necmettin Erbakan University, Faculty of Engineering, Departmant of Food Engineering, Konya, Turkey, (ORCID: 0000-0002-7692-9700), \\ gozugur@erbakan.edu.tr
}

(1st International Conference on Applied Engineering and Natural Sciences ICAENS 2021, November 1-3, 2021)

(DOI: 10.31590/ejosat.1013135)

\begin{abstract}
ATIF/REFERENCE: Üçok, G. (2021). Effect of Different Ultrasonic Amplitude Treatments on Corn Starch Gels. European Journal of Science and Technology, (28), 1133-1136.
\end{abstract}

\begin{abstract}
In this study, the effects of different amplitudes at high power ultrasound of $20 \mathrm{kHz}$ on the syneresis and textural properties of corn starch suspensions were examined. Suspensions were treated with 10, 30, and 70\% amplitude for 30 min using an ultrasound probe. While ultrasound treatments caused syneresis, no syneresis was observed in the control gel. It was observed that the rate of syneresis decreased with the increase of the ultrasound amplitude percentage, and also increased significantly after $48 \mathrm{~h}$ of storage. The ultrasound treatments caused a marked decrease of the gel mechanical properties. In particular, the reduction of ultrasound amplitude made the gels more brittle, it also caused the rupture and gel strength to decrease. The results obtained in this study showed that ultrasound technology can be used to adjust the gel strength of corn starch solutions used in food and other industries.
\end{abstract}

Keywords: Corn starch gel, Ultrasound, Gel strength, Rupture strength, Brittleness, Syneresis.

\section{Farklı Ultrason Genlik Uygulamalarının Mısır Nişastası Jelleri Üzerindeki Etkisi}

$\ddot{O} \mathbf{z}$

Bu çalışmada, 20 kHz'lik farklı genliklerdeki yüksek güçlü ultrasonun mısır nişastası süspansiyonlarının sineresis ve tekstürel özellikleri üzerindeki etkileri incelenmiştir. Süspansiyonlar, bir ultrason probu kullanılarak \%10, \%30 ve \% 70 dalga genliğinde 30 dakika boyunca muamele edilmiştir. Ultrason uygulaması jellerde sineresis oluşumuna neden olurken, kontrol jelinde sineresis gözlenmemiştir. Sineresis oranlarının uygulanan ultrason genlik yüzdesinin artmasıyla azaldığı ve 48 saatlik depolama sonrasında ise önemli ölçüde arttığ1 gözlenmiştir. Ultrason uygulaması, jellerin mekanik özelliklerinde belirgin bir düşüşe neden olmuştur. Özellikle ultrason genliğinin azalması jelleri daha kırılgan hale getirerek, kırılma mukavemetinin ve jel gücünün azalmasına neden olmuştur. Bu çalışmada elde edilen sonuçlar, gıda ve diğer endüstrilerde kullanılan mısır nişastası çözeltilerinin jel gücünü ayarlamak için ultrason teknolojisinin kullanılabileceğini göstermiştir.

Anahtar Kelimeler: Mısır nişastası jeli, Ultrason, Jel gücü, Kırılma mukavemeti, Kırılganlık, Sineresis.

\footnotetext{
* Corresponding Author: gozugur@erbakan.edu.tr
} 


\section{Introduction}

In the food industry, starch is widely used as a thickener, gelling agent, emulsifier, and stabilizer. Starch is actively preferred because it is natural, non-toxic, easy to obtain, and constantly renewing production resources (Kalinina et al., 2020). Starch obtained from corn constitutes an important basis for food production. Corn starch is used in its natural form or as a chemically modified food ingredient to thicken liquids and add other desirable textural properties to foods. It can also be used in the production of sweeteners such as corn syrup, producing ethanol, in the paper industry, and also as a binder in drywall and other building materials, adhesives, and in the development of thermoplastics and polyurethanes (Hallauer, 2001).

Ultrasound (US) is sound above the threshold of the human ear (above $18 \mathrm{kHz}$ ). The treatment of ultrasound has enormous potential for a wide variety of processes in the food industry. Ultrasound has many areas of use in food processing such as microbial inactivation, extraction (release of active substances in the plant), filtration, drying, emulsification, homogenization, crystallization (formation of smaller ice crystals in ice cream), separation, viscosity change, defoaming, and extrusion (Iida, Tuziuti, Yasui, Towata, \& Kozuka, 2008; Jambrak et al., 2010).

Ultrasonication used during the processing of starch-based foods or ingredients can affect the product properties, and cause the food properties to change.

Ultrasonic treatment, which is also used as a physical starch modification method, has significant advantages in terms of higher selectivity, reduction of chemicals uses and processing time, and ease of integration into the process flow. Therefore, ultrasonication serves the concept of "green chemistry and technology" as an environmentally friendly process (Kalinina et al., 2020; Zhu, 2015).

In this study, different amplitudes of ultrasound were treated to corn starch solutions, and the syneresis and mechanical properties of the gels were investigated.

\section{Material and Method}

The corn starch (Selva Food Industry Inc., Konya) used in the study was obtained from a local market. Its composition is declared by the manufacturer as $88 \%$ starch, $0.45 \%$ protein, and $0.1 \%$ fat. Starch solutions were prepared using distilled water.

\subsection{Sample Preparation}

Corn starch solutions were prepared to contain $10 \%$ dry matter. After the solutions were heated to approximately $60 \pm 2{ }^{\circ} \mathrm{C}$ on a magnetic stirrer, they were subjected to ultrasound treatment for 30 min. Ultrasound treatment (Bandelin Sono Puls, HD 2200, Berlin, Germany) was performed at $20 \mathrm{kHz}$ frequency voltage, $200 \mathrm{~W}$ output, and in 3 different amplitudes as $10 \%, 30 \%$, and $70 \%$ in solutions with a volume of $400 \mathrm{ml}$. The SH $225 \mathrm{G}$ booster horn was used during the process, according to which 10,30 , and $70 \%$ power correspond to $5.1,15.3$, and $35.7 \mu \mathrm{m}$ displacement (peak to peak), respectively. The temperature was kept constant at $60 \pm 2{ }^{\circ} \mathrm{C}$ throughout the ultrasound process. Then, the solution temperatures were allowed to reach about $80^{\circ} \mathrm{C}$ within $15 \mathrm{~min}$ by mixing with a magnetic stirrer. The control sample was prepared at $60{ }^{\circ} \mathrm{C}$ for the first $30 \mathrm{~min}$ and gradually increased to $80^{\circ} \mathrm{C}$ for the next $30 \mathrm{~min}$. The solutions were divided into jars as $40 \mathrm{ml}$ and stored with the lid closed at $+4{ }^{\circ} \mathrm{C}$ after coming to room temperature. Analyses of the samples were carried out after $2 \mathrm{~h}$ and $48 \mathrm{~h}$ of storage. The measurements were performed at least four times.

In the study, samples treated $10 \%, 30 \%$, and $70 \%$ ultrasonic amplitude were named as $10 \% \mathrm{US}, 30 \% \mathrm{US}$, and $70 \% \mathrm{US}$, respectively.

\subsection{Determination of Syneresis}

Syneresis measurements indicating the degree of water release of the gels were determined according to Charoenrein, Tatirat, and Muadklay (2008) with some modifications. Accordingly, approximately $10 \mathrm{~g}$ of the gel sample was centrifuged (Awel MF20, Blain, France) at $15000 \times \mathrm{g}$ for $15 \mathrm{~min}$. The separated supernatant was weighed. The percentage of syneresis was calculated by the following formula:

$$
\text { Syneresis }(\%)=\frac{W_{w}}{W_{i}} \times 100
$$

where $\mathrm{W}_{\mathrm{w}}$ is the weight of water left from the gel after centrifuge, $W_{i}$ is the initial weight of the gel before centrifuge.

\subsection{Mechanical Properties of Corn Starch Gels}

Mechanical measurements of the gel samples were performed after approximately $1 \mathrm{~h}$ they were removed from the refrigerator. Gel strength, rupture strength and brittleness values of gels were determined using a Model TA-XT Plus texture analyser (Stable Microsystems, Surrey, UK) with a $5 \mathrm{kN}$ load cell equipped with a $12.7 \mathrm{~mm}$ diameter flat-faced cylindrical plunger. Gel strength determined as maximum force $(\mathrm{g})$ for the plunger to depress by $4 \mathrm{~mm}$ the surface of a gel with a standard 0.5 " diameter cylinder probe at a rate of $0.5 \mathrm{~mm} / \mathrm{s}$. Rupture strength and brittleness tests were conducted at a crosshead speed of $1 \mathrm{~mm} / \mathrm{s}$ by compressing the sample until rupture.

\subsection{Statistical Analysis}

Results are given as mean \pm standard deviation. Differences between mean values were assessed at $\mathrm{P}<0.05$ with the Tukey multiple comparison test using SPSS 22.0.1 (SPSS Inc., New York, USA).

\section{Results and Discussion}

Corn starch syneresis analysis results are given in Fig. 1. No syneresis was observed in the control gels both on the first day and after $48 \mathrm{~h}$. The highest syneresis was in the samples treated at $10 \%$ amplitude of US, and the lowest was at $70 \%$. In general, syneresis increased with US treatment, whereas it decreased as US amplitude increased. At the same time, it was observed that the amount of syneresis increased with storage in the US-treated samples. 


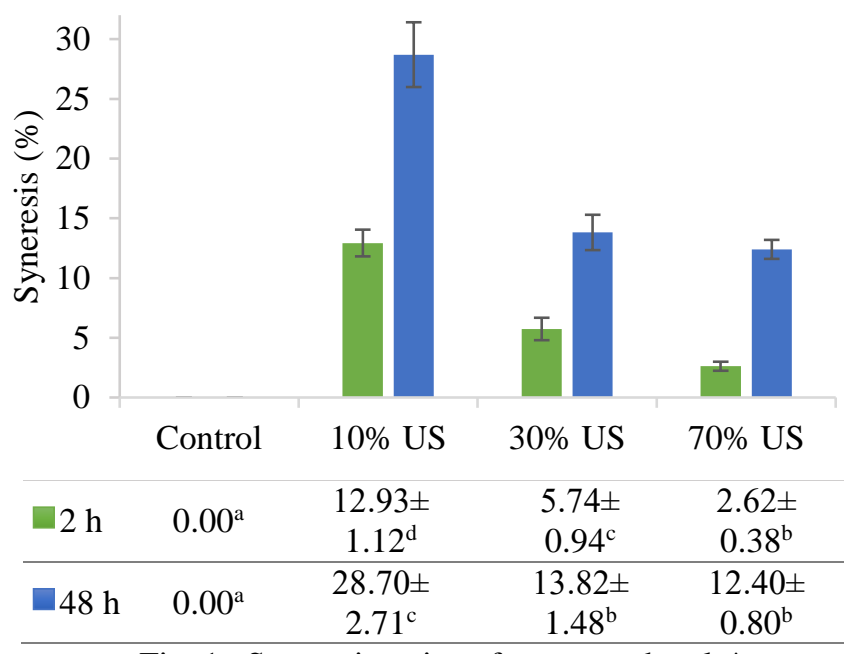

Fig. 1. Synereris ratios of corn starch gels*

*Error bars show standard deviation (SD). Result are mean \pm $\mathrm{SD}$. Mean values followed by different lower-case superscript within the same line are significantly $(\mathrm{P}<0.05)$ different in the same analysis time.

It was determined by $\mathrm{A}$. $\mathrm{Hu}$ et al. (2014) that the water released by the ultrasound applied starch grains after freezing and thawing raised with the increase of the time and frequency of US application. Similarly, Falsafi et al. (2019) found that the syneresis of oat starch gels prepared from the sonicated granules was significantly higher than that of the control starch gel.

Rupture strength is the maximum force at the fracture point of the gel. The distance the probe enters just before the gel breaks, gives the gel brittleness. The shortening of this distance is an indication of the increased brittleness of the gel, and the lengthening is an indicator of increased elasticity (Pycia, Juszczak, Gałkowska, \& Witczak, 2012; Raina, Singh, Bawa, \& Saxena, 2006).

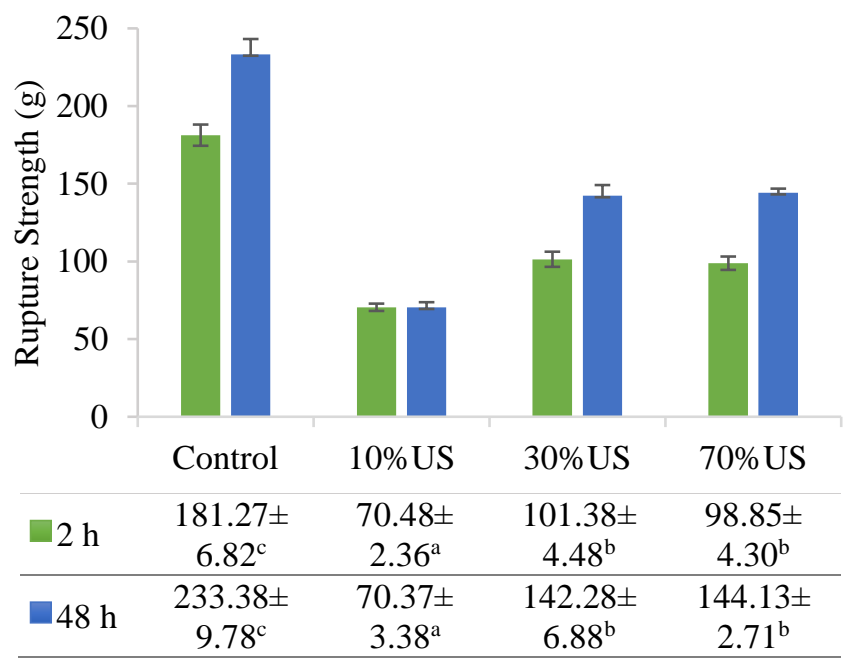

Fig. 2. Rupture strength (g) of corn starch gels*

*Error bars show standard deviation (SD). Result are mean \pm SD. Mean values followed by different lower-case superscript within the same line are significantly $(\mathrm{P}<0.05)$ different in the same analysis time.

As the rupture strength and brittleness give the gel its hardness and flexibility during rupture, respectively, these two indicators do not represent the overall quality of the gel. The gel e-ISSN: 2148-2683 strenght, which indicates the force received by the probe at the point of maximum penetration distance, is used to express the entire texture of the gel (W.-X. Hu, Chen, Zhao, Chen, \& Wang, 2020).

The rupture strength and brittleness values of the gels are given in Fig. 2 and 3, respectively. The highest rupture strength was seen in the control sample, while the lowest was in the $10 \%$ US sample. There was no statistical difference between the rupture strength of starch $30 \%$ US and $70 \%$ US gels. In general, it was determined that the US treatment, especially low amplitude, decreased the rupture strength.

It was observed that the brittleness value of the samples was the highest in the control sample and increased with storage. This was followed by a $30 \%$ US sample, however, a decrease was also seen with the effect of storage. $10 \% \mathrm{US}$ and $70 \% \mathrm{US}$ samples were unaffected by storage. The lowest brittleness was in the $10 \% \mathrm{US}$ sample.

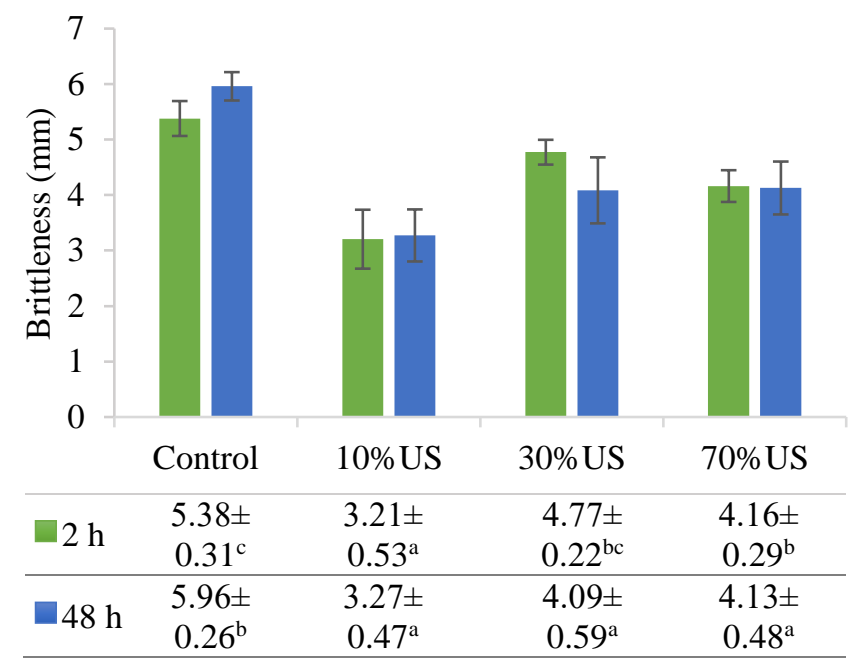

Fig. 3. Brittleness (mm) of corn starch gels*

*Error bars show standard deviation (SD). Result are mean \pm SD. Mean values followed by different lower-case superscript within the same line are significantly $(\mathrm{P}<0.05)$ different in the same analysis time.

The gel strength of the samples also differed with the US application (Fig. 4). The control sample had the highest gel strength and did not change with storage. On the other hand, the gel strength of the US-treated samples showed similarities with the rupture strength. It was determined that the gel strength of the samples, which were applied 30 and $70 \%$ US, increased significantly with the effect of storage.

Herceg et al. (2010) reported that with increasing ultrasound power, starch granules were mechanically damaged more, especially in the amorphous region. They also found that corn starch gels prepared from ultrasound probe-treated suspensions gave a higher hardness and higher adhesiveness and cohesiveness values than untreated or ultrasound bath treated suspensions.

Raina et al. (2006) found that the gel strength, rupture strength and brittleness of rice starch gels stored at $4{ }^{\circ} \mathrm{C}$ were lower than gels stored at $25{ }^{\circ} \mathrm{C}$, attributing this to the harder texture and reduced elasticity of the gels stored at low temperature. 


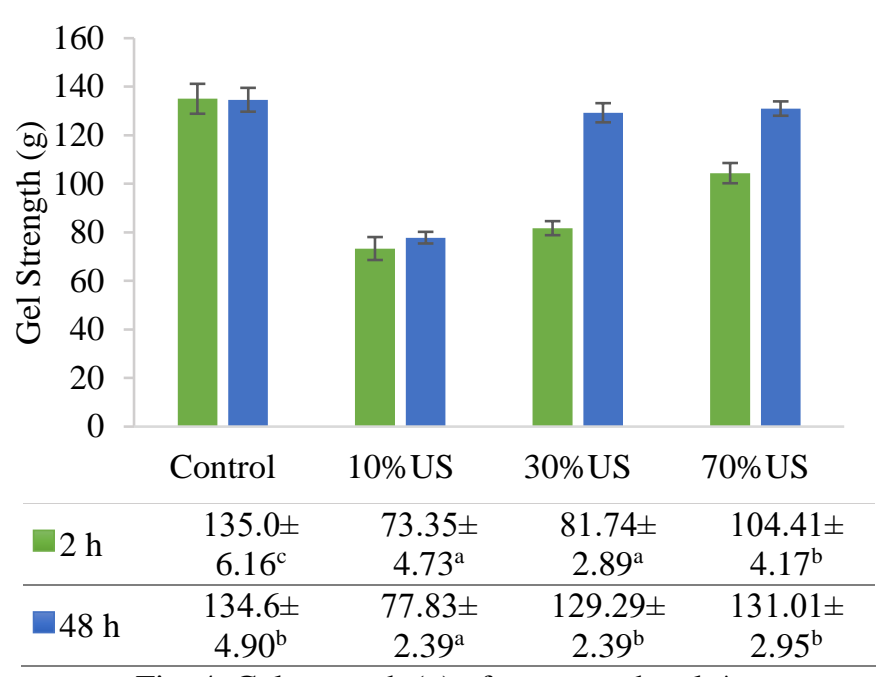

Fig. 4. Gel strength $(\mathrm{g})$ of corn starch gels*

*Error bars show standard deviation (SD). Result are mean \pm $\mathrm{SD}$. Mean values followed by different lower-case superscript within the same line are significantly $(\mathrm{P}<0.05)$ different in the same analysis time.

\section{Conclusions and Recommendations}

The mechanical properties of the gels obtained after highfrequency US application were adversely affected and the syneresis event in of the gels increased. It may have increased the amount of syneresis as a result of not forming a strong gel structure. Also, syneresis increased with the retrogradation that occurred with storage. It can be concluded that the rupture strength decreases with the increase in the syneresis rate of the samples. At the same time, the rate of syneresis increasing with storage may have increased the gel strength.

It is estimated that the collapse of the cavitation bubbles formed by the ultrasound process breaks the starch granules and mechanically damages the gel formed afterward. However, here, the greatest damage occurs at the low amplitude rate, while these losses can be tolerated as the amplitude increases.

According to the results of this study, it was concluded that gels with different mechanical properties can be obtained with the selected US amplitude. Consequently, softer gels can be produced using US treatment and the rate of syneresis can be controlled by amplitude adjustment.

\section{References}

Charoenrein, Sanguansri, Tatirat, Orawan, \& Muadklay, Janya. (2008). Use of centrifugation-filtration for determination of syneresis in freeze-thaw starch gels. Carbohydrate Polymers, 73(1), 143-147.

doi: https://doi.org/10.1016/j.carbpol.2007.11.012

Falsafi, Seid Reza, Maghsoudlou, Yahya, Rostamabadi, Hadis, Rostamabadi, Mohammad Mahdi, Hamedi, Hassan, \& Hosseini, Seyed Mohammad Hashem. (2019). Preparation of physically modified oat starch with different sonication treatments. Food Hydrocolloids, 89, 311-320. doi: https://doi.org/10.1016/j.foodhyd.2018.10.046

Hallauer, Arnel R. (2001). Specialty corns (2nd ed.). Boca Raton: CRC press.

Herceg, Ivana Ljubić, Jambrak, A Režek, ŠubArIć, Drago, Brnčić, M, Brnčić, S Rimac, Badanjak, Marija, . . . Herceg, Zoran.
(2010). Texture and pasting properties of ultrasonically treated corn starch. Czech journal offood sciences, 28(2), 8393.

Hu, Aijun, Li, Li, Zheng, Jie, Lu, Jing, Meng, Xin, Liu, Yan, \& Rehman, Rizwan-ur-. (2014). Different-frequency ultrasonic effects on properties and structure of corn starch. Journal of the Science of Food and Agriculture, 94(14), 2929-2934. doi: https://doi.org/10.1002/jsfa.6636

$\mathrm{Hu}$, Wen-Xuan, Chen, Jie, Zhao, Jing-Wen, Chen, Ling, \& Wang, Yuan-Hui. (2020). Effect of the addition of modified starch on gelatinization and gelation properties of rice flour. International Journal of Biological Macromolecules, 153, 26-35. doi: https://doi.org/10.1016/j.ijbiomac.2020.03.002

Iida, Yasuo, Tuziuti, Toru, Yasui, Kyuichi, Towata, Atsuya, \& Kozuka, Teruyuki. (2008). Control of viscosity in starch and polysaccharide solutions with ultrasound after gelatinization. Innovative Food Science \& Emerging Technologies, 9(2), 140-146. doi: https://doi.org/10.1016/j.ifset.2007.03.029

Jambrak, Anet Režek, Herceg, Zoran, Šubarić, Drago, Babić, Jurislav, Brnčić, Mladen, Brnčić, Suzana Rimac, . . Gelo, Jurica. (2010). Ultrasound effect on physical properties of corn starch. Carbohydrate Polymers, 79(1), 91-100. doi: https://doi.org/10.1016/j.carbpol.2009.07.051

Kalinina, Irina, Ruskina, Alena, Fatkullin, Rinat, Naumenko, Natalya, Potoroko, Irina, Sonawane, Shirish, \& Shaik, Shabana. (2020). The application of ultrasound for the regulation of the starch gel viscosity. Bulgarian Journal of Agricultural Science, 26(3), 690-695.

Pycia, Karolina, Juszczak, Lesław, Gałkowska, Dorota, \& Witczak, Mariusz. (2012). Physicochemical properties of starches obtained from Polish potato cultivars. Starch Stärke, 64(2), 105-114. doi: https://doi.org/10.1002/star.201100072

Raina, C. S., Singh, S., Bawa, A. S., \& Saxena, D. C. (2006). Some characteristics of acetylated, cross-linked and dual modified Indian rice starches. European Food Research and Technology, 223(4), 561-570. doi: 10.1007/s00217-0050239-z

Zhu, Fan. (2015). Impact of ultrasound on structure, physicochemical properties, modifications, and applications of starch. Trends in Food Science \& Technology, 43(1), 1-17. doi: https://doi.org/10.1016/j.tifs.2014.12.008 